\title{
FLOATING SOLAR PV-HYDROELECTRIC POWER PLANTS IN BRAZIL: ENERGY STORAGE SOLUTION WITH GREAT APPLICATION POTENTIAL
}

\author{
JAIR ARONE MAUÉS \\ Petrobras Gas \& Power Area, Brazil.
}

\begin{abstract}
Photovoltaic (PV) solar farms and hydropower stations can create a plant that do more than the two resources acting independently as long as, with the addition of a solar project, hydroelectric plants increase its annual availability of power and economic efficiency, taking advantage of the storage capacity of energy that a hydroelectric reservoir can provide. The objective of this paper is to investigate the potential of Brazilian hydropower plants regarding these issues using the large amount of available data recorded. There exists a potential increase in the energy production of $53.3 \mathrm{TWh}$ per year based on the proposed optimized solution for the Brazilian hydropower stations with significant water storage capacities assessed in this paper. This energy is equivalent to an additional capacity factor of approximately $20 \%$ to the original $31.5 \mathrm{GW}$ installed hydro capacity or almost $10 \%$ of the Brazilian electricity demand in 2018. This result would be at the expenses of a huge deployment of $34 \mathrm{GW}$ of solar PV floating power plants installed close to the reservoir dams that must yet prove to be economically feasible. However, on the other hand, this proposal can create a virtuous cycle for the solar industry in Brazil and speed up the viability of solar cell costs, since setting up and connecting the PV plants are greatly simplified when done in existing hydropower stations facilities.
\end{abstract}

Keywords: Energy Storage, Floating Photovoltaic, Hybrid Power Plant, Hydropower.

\section{INTRODUCTION}

The potential that energy storage solutions offer in managing renewable intermittency will see an increased importance as the proportion of renewable generation continues to grow. The use of small amounts of intermittent power has little effect on electrical grid operations but larger penetration of variable power can affect the grid's ability to operate as required. This is the case in Brazil with the enormous increase in wind generation in the past decadeover $14 \mathrm{GW}$ installed in 2018, 45\% increase capacity per year since 2008 [1].

Hybrid power plants can mitigate these issues by combining generation resources with the intent of using their respective performance characteristics to compensate for each other's shortcomings. Brazilian hydroelectric power stations are very well monitored since the country's integrated electrical power system was strongly based on this resource from the 1960s. The objective of this paper is to prove that, if well planned, these hybrid plants can perform better than the sum of its parts and do more than the two resources acting independently.

Hybrid solar and hydro power stations are very rare but, since 2013, a 850 MW PV plant, covering a $24 \mathrm{~km}^{2}$ area, connected directly to the hydro turbine units has been added to the existing 1,280 MW Longyangxia hydroelectric station in Qinghai Province, north-west of China, along the Yellow river. The hydropower plant was designed and commissioned in 1992 with a water reservoir which supports four 320 MW quick-response turbines. These turbines smooth the irregular output curve of the PV power, caused by natural fluctuations in sunlight. As a result, the hybrid combined power generation improves the exploration of an intermittent energy source providing better and more reliable power to the grid [2].

In Brazil, hydroelectricity is responsible for approximately $70 \%$ of the power generated and of the total $166 \mathrm{GW}$ installed in the country, $114 \mathrm{GW}$ are hydroelectric plants of all 
capacities. A huge hydro energy potential still exists there, but most of it lies on the Northern region of Brazil, where power demand is low and very large reservoirs are necessary in order to stabilize power production [3].

The capacity to store water in reservoirs of hydropower plants (HPP) has declined, due to the increased Brazilian electricity consumption as well as due to the more stringent environmental conditions for flooding areas, which the new projects must meet. Therefore, the risk of power deficit increases in the case of prolonged water shortage. The drought that occurred in 2001 prompted the federal government to diversify energy supply sources, favoring the inclusion of a reasonable share of thermal power plants, most powered by natural gas. It also created a market share for other renewable sources of energy, namely wind, biomass and solar.

However, there are still many hydropower stations with significant water reservoirs (see Table 1) and they could improve in the same way that Longyangxia HPP has been upgraded. However, different from China, the proposal in Brazil is to use floating solar systems to accomplish this synergy. The reason for this is the great value achieved by the properties adjacent to the reservoirs because water can be used for irrigation in agricultural areas or, in more populated regions, a real estate business can be developed for recreational or even housing purposes, if not defined an area of environmental preservation.

These HPPs, total $31.5 \mathrm{GW}$, approximately comprise $28 \%$ of the installed Brazilian hydropower capacity. They also represent important hydro plants concerning the regularization of the interconnected electrical system, with long available historical operational data. It does not mean other HPPs do not have potential or cannot even be better candidates for upgrading. They just have less data available, reason why Balbina HHP (see next section) was not included in the list, or they are 'run-of-the-river' kind, which has a small reservoir in comparison to the river flow, with water volume accumulation practically null.

Table 1: Hydropower stations with significant water storage reservoirs assessed [4].

\begin{tabular}{llccccc}
\hline \# & HPP & Region & River & $\begin{array}{c}\text { Power } \\
\text { MW }\end{array}$ & $\begin{array}{c}\text { Reservoir } \\
\text { Area - km }\end{array}$ & Concessionary \\
\hline 1 & Tucuruí & $\mathrm{N}$ & Tocantins & 8,370 & 2,850 & ELETRONORTE \\
2 & Ilha Solteira & SE & Paraná & 3,444 & 1,195 & CESP \\
3 & Itumbiara & SE & Paranaíba & 2,082 & 778 & FURNAS \\
4 & São Simão & SE & Paranaíba & 1,710 & 703 & SPIC \\
5 & Foz do Areia & S & Iguaçu & 1,676 & 167 & COPEL \\
6 & Itaparica & NE & São Francisco & 1,480 & 828 & CHESF \\
7 & Marimbondo & SE & Grande & 1,440 & 438 & FURNAS \\
8 & Salto Santiago & S & Iguaçu & 1,420 & 208 & ENGIE \\
9 & Água Vermelha & SE & Grande & 1,396 & 647 & AES TIETE \\
10 & Serra da Mesa & MW & Maranhão & 1,275 & 1,784 & FURNAS \\
11 & Furnas & SE & Grande & 1,216 & 1,440 & FURNAS \\
\hline
\end{tabular}




\begin{tabular}{|c|c|c|c|c|c|c|}
\hline 12 & Emborcação & SE & Paranaíba & 1,192 & 477 & CEMIG \\
\hline 13 & Sobradinho & $\mathrm{NE}$ & São Francisco & 1,050 & 4,214 & CHESF \\
\hline 14 & Três Irmãos & SE & Tietê & 808 & 785 & CESP \\
\hline 15 & Capivara & SE & Paranapanema & 619 & 576 & DUKE \\
\hline 16 & Nova Ponte & SE & Araguari & 510 & 449 & CEMIG \\
\hline 17 & $\begin{array}{l}\text { Mascarenhas de } \\
\text { Moraes }\end{array}$ & $\mathrm{SE}$ & Grande & 476 & 250 & FURNAS \\
\hline 18 & Chavantes & SE & Paranapanema & 414 & 400 & DUKE \\
\hline 19 & Três Marias & SE & São Francisco & 396 & 1,040 & CEMIG \\
\hline 20 & Promissão & SE & Tietê & 264 & 530 & AES TIETÊ \\
\hline 21 & Barra Bonita & $\mathrm{SE}$ & Tietê & 141 & 310 & AES TIETÊ \\
\hline \multirow[t]{2}{*}{22} & Jurumirim & SE & Paranapanema & 101 & 449 & DUKE \\
\hline & TOTAL & & & 31,479 & 20,518 & \\
\hline
\end{tabular}

\section{FLOATING PHOTOVOLTAIC SOLAR INSTALLATIONS}

Floating solar photovoltaic (PV) installations consist of systems installed on water ponds, lakes and reservoirs owned by water or power utilities companies. The advantages over ground and roof-mounted systems come from preserving valuable land for other uses and operating at a higher efficiency, due to the natural cooling effect of the water.

Floating solar PV systems face fewer barriers than ground-mounted PV. Foundation structural works are not required and the deployment of the solar modules itself is quite straightforward. Beneficial collateral effects include reducing water evaporation and limitation of algal growth in the reservoirs. The major structural drawbacks for these systems are the requirement of waterproof components and floating structures attached to cables able to withstand water level variations and/or adverse climate conditions, like strong winds. Operation and maintenance are as simple and safe as in a ground-mounted plant and there is no need to transport water for cleaning the solar collectors, since it is available on the spot. At last, if there are nearby grid-connection infrastructures, which is the case of hydropower reservoirs, it greatly alleviates the financial cost of setting up and connecting the PV plant [5], [6].

Many countries have already started experimenting with floating PV plants, including Brazil. Only three floating solar plants had ever been built before 2014 but, over the past four years, this number has surpassed 100 plants spread across the world, more than half of them in Japan, where the lack of proper land has pushed developers to find solutions on the water [7].

In Brazil, the first two floating solar power systems at Balbina HPP, located in Northern Amazon Region, and at Sobradinho HPP, in the Northeast Region, have already started operation. Both arrays were planned to deliver a maximum $1 \mathrm{MW}$ each at the first stage of the project with a further $4 \mathrm{MW}$ to be added in sequential events. The project is aiming to evaluate the performance of floating solar arrays installed in the lake of hydroelectric power plants in regions with different climatic regimes. The energy generated by the panels can supplement the hydroelectric power plants, taking advantage of the transmission structure already installed. The research and development project targets up to a $300 \mathrm{MW}$ installation in Balbina, which has a 250 MW HPP capacity. 
Nevertheless, the development of a basic study of this kind of system, as done here, is highly advisable in order to improve the profitability of construction and operation of utility-scale floating solar plants in the future.

\section{SOLAR GENERATION SYNERGY WITH HYDROPOWER IN BRAZIL}

Hydropower has several advantages over other power sources such as quick startup and shutdown and it plays a fundamental role in the Brazilian electrical system, covering from base to peak load and providing emergency reserves when a large water reservoir is available.

A solar PV floating power plant located on the hydro station reservoir could operate in a complementary mode, improving the power quality of PV output and/or providing surplus water storage in depleted hydro basins. The complementary hydro/PV operation is accomplished by making the random output curve of PV power be stabilized by rapidly adjustable hydropower units. When a large-scale solar power plant combines with a hydropower station, it is possible to store the generated electricity without changing the basic HPP facilities.

Any solar power generated can allow a corresponding reduction in the water flow through the hydropower turbines, conserving that water for later use, when it is potentially more valuable, such as in the early evening, a frequent peak load time.

In most hydropower installations it is not feasible to generate power at full capacity 24 hours per day because the annual dam water catchment is not enough to sustain the required average flow rate through the turbines and, consequently, the electrical grid transmission lines can be considerably underused. The annual average capacity factor (CF) for most hydropower stations surveyed in this study are under $50 \%$.

Since the annual water flow availability of a hydroelectric plant is the main limit factor to produce energy, a co-located solar component of generation can increase the dispatchable energy production, making better usage of the hydro plant's electrical grid connection.

\subsection{Methodology and data sources for HPPs}

Electric System National Operator (ONS) is a Brazilian agency responsible for coordinating and controlling the operation of electricity generation and transmission facilities in the National Interconnected System (SIN). It maintains and regularly discloses to the Brazilian society a historical database with the main parameters of SIN's operation, which includes information on storage levels of reservoirs, water affluence to hydroelectric plants, among others, on monthly basis [4].

Therefore, from this database, water reservoirs useful volumes as a percentage of their maximum values are calculated and they will work as a basic unit in the analysis performed here. Both hydropower and solar PV generation are represented as an equivalent volume of water in the reservoir needed to be discharged through the hydro plant's turbines in order to produce the same amount of energy.

Sobradinho HPP will serve as an example case to demonstrate how the methodology develops to compile data from all HPPs under analysis in this paper. Table 2 shows hydro plant basic necessary information.

The first parameter to be included in this survey is the theoretical time to drain the reservoir useful volume at a condition of zero water supply and turbines operating at full capacity (drainage time, DT). In Sobradinho HPP, it would take approximately 78 days. 
Table 2: Sobradinho HPP data.

\begin{tabular}{lc}
\hline Plant Capacity, P & $1,050 \mathrm{MW}$ \\
\hline Location & $-9^{\circ} 25^{\prime} 49^{\prime \prime},-40^{\circ} 49^{\prime} 37^{\prime \prime}$ \\
Normal Storage Area - A & $4,214 \mathrm{~km}^{2}$ \\
Water Reservoir Useful Volume - V & $28,669 \times 10^{6} \mathrm{~m}^{3}$ \\
Turbines Flow Discharge - Q & $4,260 \mathrm{~m}^{3} / \mathrm{s}$ \\
\hline
\end{tabular}

$$
\mathrm{DT}_{\text {Sobradinho }}=\mathrm{V} / \mathrm{Q}=\frac{28,669,000,000 \mathrm{~m}^{3}}{4,260 \frac{\mathrm{m}^{3}}{\mathrm{~s}} * 3,600 \frac{\mathrm{s}}{\mathrm{h}}}=1,869 \text { hours or } 78 \text { days }
$$

The second is the Water Reservoir Energy Equivalence (E). 100\% of Sobradinho water reservoir useful volume - 28,669 million $\mathrm{m}^{3}$ - could generate a total electricity amount of $1,963 \mathrm{GWh}$, as a nominal flow of $4,260 \mathrm{~m}^{3} / \mathrm{s}$ of water discharged through the turbines from the normal reservoir level is able to produce $1.05 \mathrm{GW}$ of power.

$$
\mathrm{E}_{\text {Sobradinho }}=\mathrm{DT}_{\text {Sobradinho }} \times \mathrm{P}=1,869 \mathrm{hrs} \times 1.05 \mathrm{GW}=1,963 \mathrm{GWh}
$$

Moreover, $1 \%$ of water reservoir useful volume is equivalent to $19.6 \mathrm{GWh}$ and this percentage (L) can be adopted to evaluate the electricity produced from either a hydro or a solar source. Actually, a higher volume of water would be necessary to generate $19.6 \mathrm{GWh}$ if the water reservoir level reached its minimum operational value and, for example, the equivalent PV power generation would be more than $1 \%$ of the water reservoir useful volume, if the reservoir water level were lower than the normal level. In this case, power production is affected and more water flow would be necessary to keep the power output. However, for simplifying the survey, we have neglected this effect, as there is a natural compensation for the solar system if the reservoir is emptying or filling.

\subsection{Methodology and data sources for solar plants}

The solar radiation reaching the earth's surface equals about 1 kilowatt per square meter $\left(\mathrm{kW} / \mathrm{m}^{2}\right)$ in clear conditions when the sun is near the zenith. It has two components: direct or 'beam'radiation, which comes directly from the sun's disk, and diffuse radiation, which comes indirectly, after being scattered in all directions by the atmosphere. Global solar radiation is the sum of the direct and diffuse components. Global horizontal irradiance (GHI) is a measure of the density of the available solar resource per unit area on a plane horizontal to the earth's surface [8].

National Renewable Energy Laboratory (NREL), in order to facilitate investments in solar and wind energy projects, has provided, via its SWERA Project (Solar and Wind Energy Resource Assessment), a geo-spatial toolkit that uses a geographical information system designed to compile solar irradiance data in developing countries, including Brazil [9]. In this work, we have used high-resolution GHI data from Brazilian National Institute of Spatial Research (INPE), on average monthly basis, at geographical coordinates close to the reservoir dam. Table 3 shows GHI data for the coordinates close to Sobradinho HPP reservoir dam. 
Table 3: Average GHI Data at Sobradinho Dam - Wh/m²/day [10].

\begin{tabular}{llllllll}
\hline Jan & 6,149 & Apr & 5.003 & Jul & 4,857 & 9Oct & 6,563 \\
Feb & 6,294 & May & 5,143 & Aug & 5,533 & Nov & 6,426 \\
Mar & 6,194 & Jun & 4,580 & Sep & 5,984 & Dec & 5,431 \\
\hline
\end{tabular}

Multiplying these data by solar cells area and the solar-electrical conversion efficiency factor provide PV generation average estimates. We have adopted a conversion efficiency factor of $15 \%$ based on crystalline silicon solar panels with initial efficiency of $17 \%$ and a degradation rate of $0.6 \%$ per annum during 20 years, i.e. $\eta_{\text {after } 20 \text { years }}=\eta_{\text {initial }} \times(1-0,6 \% \times 20)$ [11], [12].

In addition, total electrical losses further affect the dispatched electricity to the grid. They include conversion from direct current (DC) to alternating current (AC) and internal transmission losses up to the hydropower high voltage electrical substation, from where power is injected into the grid. Therefore, very large PV plants must consider a performance ratio (PR) or the relationship between the actual AC power output and the DC power input. PR measured within PV plants installed in desert areas of Qinghai, China, resulted in an average $75 \%$ efficiency, including losses of around 5\% related to dust accumulated on the solar panels with once a month cleaning and $5 \%$, due to increased panel temperatures above $25^{\circ} \mathrm{C} \mathrm{[13].} \mathrm{Cer-}$ tainly, floating PV plants can considerably reduce both losses. If, at least, we consider a $50 \%$ improvement in these losses, PR could reach $80 \%$.

Table 4 shows data for a hypothetical PV plant installed on Sobradinho HPP reservoir and Fig. 1, how it could be located close the dam.

Table 4: PV solar plant's data of maximum capacity—Sobradinho HPP reservoir.

\begin{tabular}{lccl}
\hline Plant Capacity $^{1}$ & $\mathbf{1 3 0 0}$ & MW & Remarks \\
\hline PV Solar Panel Converting Efficiency & 15 & $\%$ & 1. Maximum capacity equal to \\
Total Energy Losses & 20 & $\%$ & 1050 MW HPP capacity/80\% \\
PV Solar Panels Area & 9 & $\mathrm{~km}^{2}$ & PR (see section 3.3). \\
Total PV Solar Plant Area & 2. Considering a 50\% ground cover \\
Percentage of Reservoir Area & 18 & $\mathrm{~km}^{2}$ & $\begin{array}{c}\text { ratio - area of solar panels / total } \\
\text { area occupied by the plant. }\end{array}$ \\
\hline
\end{tabular}

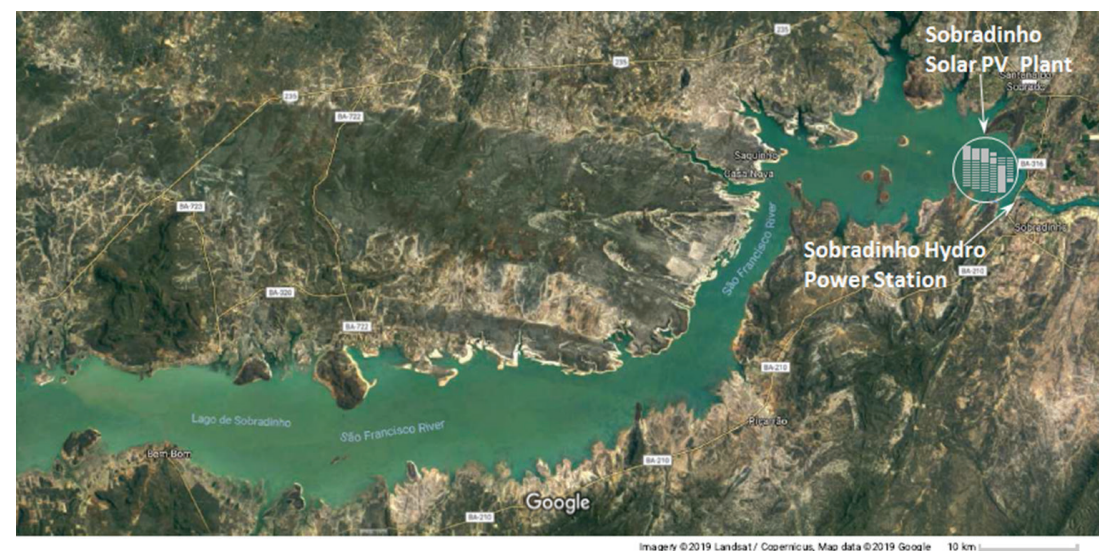

Figure 1: Hypothetical PV plant installed on Sobradinho HPP reservoir. 


\subsection{Criteria for combining a solar PV plant with a HPP}

The same way we can better design a wind farm at a specific area when longer periods of wind characteristics are accurately measured, solar and hydropower installations will deliver more energy if the availabilities of their sources are well known. This is exactly the case regarding the HPPs under analysis here and we take advantage of the data available in order to accomplish such a proposition. Therefore, all the graphics and results presented here were derived from the operational history of the assessed hydro plants.

A necessary boundary condition that a PV plant must follow in order to combine with a hydropower already in operation, without further improvements, is the maximum power the electrical transmission grid associated with the plant is able to withstand.

Although some grids are capable to transmit up to twice the HPP generation capacity, we have applied the assumption that the maximum output the PV plant is able to supply to the grid equals the HPP maximum output. So, total electrical losses up to this point are added to the solar plant capacity if this is the design criteria applied.

Secondly, the water storage availability of the hydropower reservoir must be assessed together with the solar power forecasted production, since the goal is to avoid any overflow of dam water due to extra solar power generation.

Third, we have to keep in mind that the data used for simulating plants' energy balances are monthly average based and margins must be included to compensate for specific point deviations, if a very rainy season occurs. In this case, the monthly dispatchable power capacity of the electrical grid becomes an important parameter to be considered, as it limits the amount of energy the hybrid hydro-solar system would be able to deliver.

The hydropower generation is based on the average monthly HPP electricity selling obtained from Chamber of Commercialization of Electric Energy (CCEE) datasheets [1]. Therefore, a typical graph of the combined solar and hydro generation related to each power plant can be plotted. Together with the monthly dispatchable power capacity of the grid, all these data are expressed in terms of the water reservoir useful volume percentage (L).

Two clear opposite situations happen after applying this methodology:

1. The last five years' period has experienced useful volumes of water reservoir reaching below $40 \%$ values very often. Never or very rarely reached $100 \%$. Dispatched hydroelectricity has been constrained as well due to this reason. A solar plant can generate its maximum output power equal to the electrical grid maximum capacity. The surplus water storage showed in the graph is numerically equal to the monthly solar generation, in the case of, for any reason, a call is made to accommodate the same amount of energy in order to increase the water reservoir average level. Sobradinho (Fig. 2) is an example of such a case.

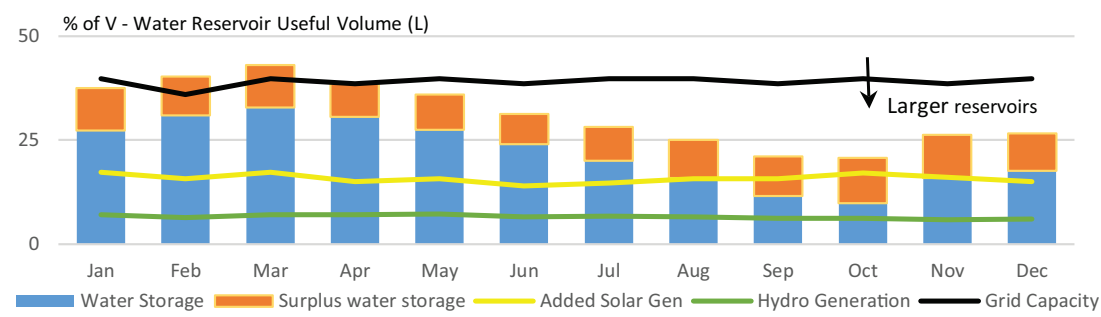

Figure 2: Sobradinho HPP 2014-18 average L and hydropower generation. 


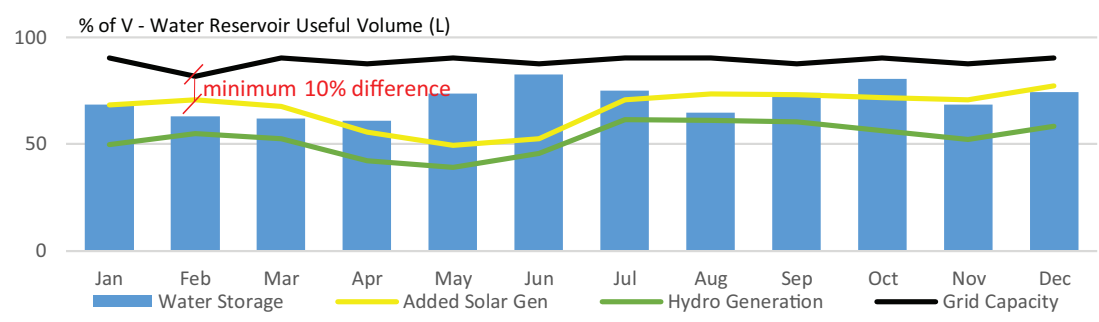

Figure 3: Salto Santiago HPP 2014-18 average L and hydropower generation.

2. Water levels of the reservoir reach frequently maximum values during wet periods. In this case, solar generation was constrained in order to ceiling up to $90 \%$ the average monthly grid utilization factor, combining hydro and solar generation, as there may be no room to accommodate a surplus water storage in very rainy seasons. Salto Santiago (Fig. 3) is an example of such a case.

\section{DISCUSSIONS OF STATISTICAL RESULTS OF WATER RESERVOIR LEVELS}

Figure 4 shows the last five years, from 2014 to 2018, of the average CF and statistical distribution of HPPs water reservoir useful volume under analysis.

Of course, if the stream's contributions to a reservoir catchment area are not enough, its level can reach critical levels and the solution when this situation arises is to reduce HPP output to a minimum value in order to keep the main river flowing after the dam.

The last five years were particularly sensitive to this case and even dispatching energy with average CFs below 35\% was not sufficient to recover normal reservoirs levels of seven HPPs. This has been a trend of Itaparica, Serra da Mesa, Furnas, Emborcação, Sobradinho, Nova
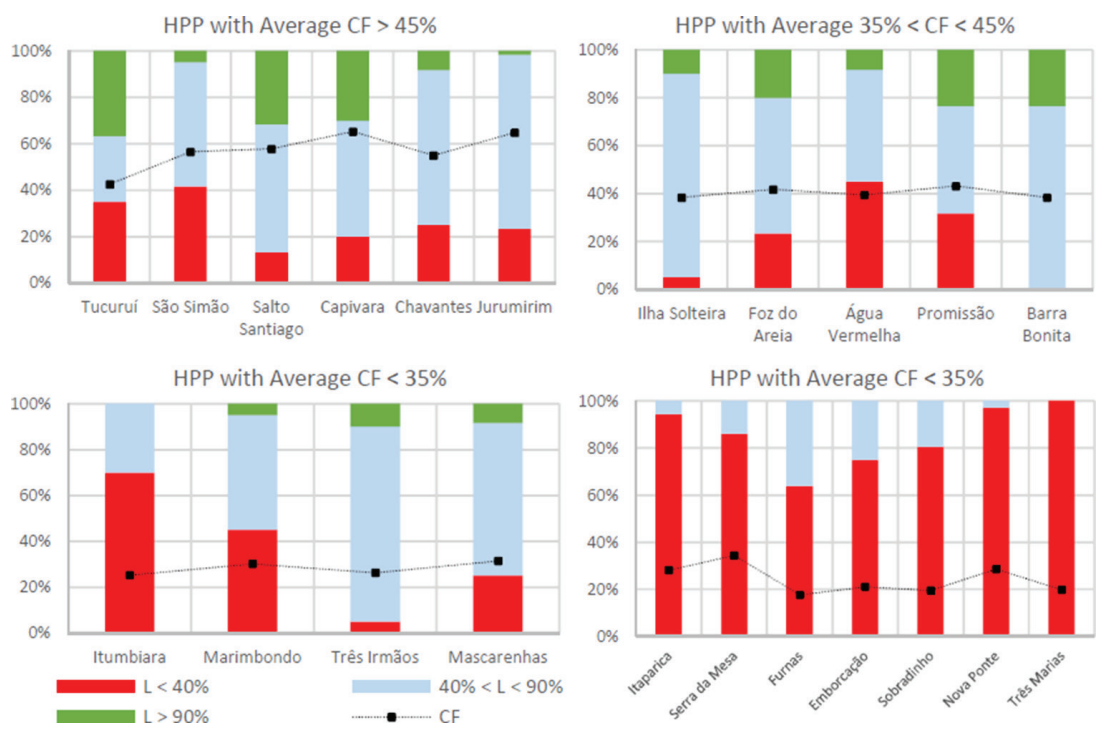

Figure 4: HPPs classified by last five years (2014-2018) average CF and statistical distribution of water reservoir useful volume percentages (L). 

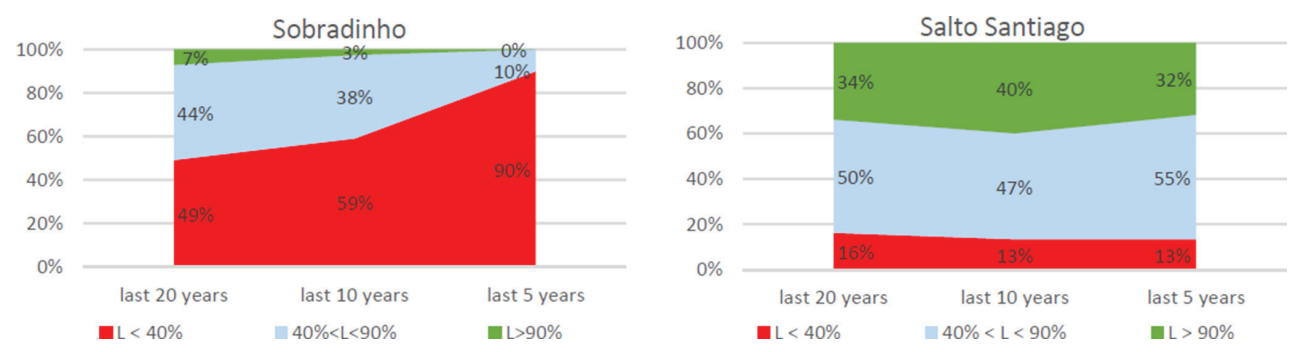

Figure 5: Statistical Distribution of $\mathrm{L}$ in a depleted versus a healthy reservoir.

Ponte and Três Marias HPP, which very rarely or never reaches its maximum reservoirs' levels. Actually, a solar PV system could serve another important purpose in this case, that is to recover water reservoir levels by keeping a reduced HPP output during longer periods. A PV solar plant and a grid connection with double capacity would allow speeding the process without wasting the peak solar generation.

On the other hand, five HPPs (Tucuruí, São Simão, Salto Santiago, Capivara, Chavantes and Jurumim) are not facing any problem regarding this subject, and we can say that they have very healthy reservoirs, even dispatching energy under high CFs. In this case, as there is no margin to accommodate a surplus water storage, solar generation constraining was applied, delimiting the average hydro and solar generation in order to produce a maximum $90 \%$ monthly electrical grid utilization factor.

Figure 5 shows the statistical distribution of water reservoir useful volume of Sobradinho and Salto Santiago HPPs comparing the last 20 (1999-2018), 10 (2009-2018) and 5 years (2014-2018).

\section{SIMULATION RESULTS}

Regarding the size and importance of the HPP to stabilize the Brazilian interconnected electrical system, the useful volume of its reservoir $(\mathrm{V})$ compared to the power installed capacity is a key factor to understand how the system improves with an added PV plant. A HPP with no or little water accumulation capacity would have to overflow during rainy seasons if a solar PV plant were implemented without an electrical grid expansion.

The time to drain the HPP water reservoir useful volume (DT), as defined in Section 3.1, is a way to evaluate it. It is interesting to notice how the water accumulation capacity of a HPP is independent of the flooded area or of its power capacity, but rather a combination of various parameters. In this work, we have arbitrarily classified a reservoir: large, if the time to empty it is above 70 days; regular, between 20 and 60 days or small, below 20 days. We have arranged HPPs according to this criterion in Table 5 and highlighted those with depleted reservoirs in red and those with healthy reservoirs, in blue.

The remaining HPPs under analysis, kept in black characters in Table 5, were able, to a greater or lesser degree, to cope with the drought prolonged periods by reducing their average power output. They have the appropriate sizes to recover their levels after a more intense rainy season or to reduce them, after few weeks of drought associated with turbines full operation. Therefore, it is still possible to propose a solar PV system based on the electrical grid maximum capacity for these HPPs, managing the wettest months, dispatching more energy to avoid a water overflow of the dam. 
Table 5: Classification of HPPs under proposed water accumulation capacity criteria.

\begin{tabular}{|c|c|c|c|c|c|c|c|}
\hline $\begin{array}{l}\text { Size of } \\
\text { Reservoir }\end{array}$ & \# & HPP & $\begin{array}{c}\text { DT } \\
\text { days }\end{array}$ & $\begin{array}{c}\text { Power } \\
\text { MW }\end{array}$ & $\begin{array}{c}1 \% \text { of } \mathrm{V} \\
\text { GWh }\end{array}$ & $\begin{array}{l}\text { Grid Capacity } \\
\% \text { of V/month }\end{array}$ & $\begin{array}{c}2014 / 18 \\
\text { CF \% }\end{array}$ \\
\hline \multirow{8}{*}{ Large } & 10 & $\begin{array}{l}\text { Serra da } \\
\text { Mesa }\end{array}$ & 441 & 1,275 & 135 & 7 & 30 \\
\hline & 16 & Nova Ponte & 248 & 510 & 30 & 12 & 29 \\
\hline & 19 & Três Marias & 193 & 396 & 18 & 15 & 19 \\
\hline & 12 & Emborcação & 155 & 1,192 & 44 & 20 & 20 \\
\hline & 11 & Furnas & 129 & 1,216 & 38 & 24 & 22 \\
\hline & 1 & Tucuruí & 114 & 8,370 & 228 & 27 & 43 \\
\hline & 22 & Jurumirim & 108 & 101 & 3 & 30 & 64 \\
\hline & 13 & Sobradinho & 78 & 1,050 & 20 & 40 & 17 \\
\hline \multirow{12}{*}{ Regular } & 18 & Chavantes & 55 & 414 & 5 & 60 & 54 \\
\hline & 5 & Foz do Areia & 53 & 1,676 & 21 & 60 & 42 \\
\hline & 3 & Itumbiara & 50 & 2,082 & 25 & 60 & 25 \\
\hline & 9 & A.Vermelha & 50 & 1,396 & 17 & 60 & 39 \\
\hline & 15 & Capivara & 50 & 619 & 7 & 60 & 65 \\
\hline & 21 & Barra Bonita & 50 & 141 & 2 & 60 & 39 \\
\hline & 8 & $\begin{array}{c}\text { Salto } \\
\text { Santiago }\end{array}$ & 34 & 1,420 & 12 & 90 & 58 \\
\hline & 4 & São Simão & 25 & 1,710 & 10 & 120 & 57 \\
\hline & 20 & Promissão & 25 & 264 & 2 & 120 & 43 \\
\hline & 7 & Marimbondo & 24 & 1,440 & 8 & 125 & 30 \\
\hline & 17 & Mascarenhas & 24 & 476 & 3 & 125 & 32 \\
\hline & 14 & Três Irmãos & 22 & 808 & 4 & 140 & 27 \\
\hline \multirow{2}{*}{ Small } & 6 & Itaparica & 15 & 1,480 & 5 & 200 & 23 \\
\hline & 2 & Ilha Solteira & 10 & 3,440 & 8 & 300 & 38 \\
\hline
\end{tabular}

We have applied the same methodology to all HPP reservoirs under analysis here and dimensioned an optimized floating PV power plant for each one of them, obeying the boundary conditions discussed before. The results presented in Table 6 show that, for most analyzed cases, the proposed PV power plant could potentially add more than $50 \%$ to the total energy delivered by the hydroelectric plant.

Installing $34 \mathrm{GW}$ of solar PV power on roughly $2.2 \%$ of total water surface of HPP reservoirs can increase energy production by $53.3 \mathrm{TWh}$ per year. This energy is equivalent to an additional CF of $20 \%$ to the original $31.5 \mathrm{GW}$ installed hydro capacity or almost $10 \%$ of the Brazilian electricity demand in 2018 [1]. 
Table 6: Results of proposed floating PV plants added to surveyed hydropower plants.

\begin{tabular}{|c|c|c|c|c|c|c|c|c|}
\hline \multirow{2}{*}{$\frac{\#}{1}$} & \multirow{2}{*}{$\begin{array}{l}\text { HPP } \\
\text { Tucuruí }\end{array}$} & \multirow{2}{*}{$\begin{array}{c}\text { HPP } \\
\text { MW } \\
8,370\end{array}$} & $\begin{array}{c}\text { PV } \\
\text { MW }\end{array}$ & PV $F$ & $\begin{array}{c}\% \text { of } \\
\text { Reservoir }\end{array}$ & \multicolumn{2}{|c|}{$\begin{array}{c}\text { Increase of } \\
\text { Annually } \\
\text { Dispatched } \\
\text { Energy } \\
\text { GWh \% }\end{array}$} & \multirow{2}{*}{$\begin{array}{c}\begin{array}{c}\text { Additional } \\
\text { HPP CF \% }\end{array} \\
14.60\end{array}$} \\
\hline & & & 6,986 & 93 & 3.27 & 10,703 & 29.26 & \\
\hline 2 & Ilha Solteira & 3,444 & 4,305 & 57 & 4.80 & 6,933 & 66.89 & 22.98 \\
\hline 3 & Itumbiara & 2,082 & 2,603 & 35 & 4.46 & 4,278 & 82.78 & 23.46 \\
\hline 4 & São Simão & 1,710 & 1,361 & 18 & 2.58 & 2,187 & 24.51 & 14.60 \\
\hline 5 & Foz do Areia & 1,676 & 2,095 & 28 & 16.73 & 2,880 & 42.02 & 19.62 \\
\hline 6 & Itaparica & 1,480 & 1,850 & 25 & 2.98 & 2,872 & 74.25 & 22.16 \\
\hline 7 & Marimbondo & 1,440 & 1,800 & 24 & 5.48 & 2,857 & 124.19 & 22.65 \\
\hline 8 & $\begin{array}{l}\text { Salto } \\
\text { Santiago }\end{array}$ & 1,420 & 1,316 & 18 & 8.44 & 1,954 & 26.01 & 15.71 \\
\hline 9 & $\begin{array}{l}\text { Água } \\
\text { Vermelha }\end{array}$ & 1,396 & 1,745 & 23 & 3.60 & 2,846 & 75.70 & 23.27 \\
\hline 10 & $\begin{array}{l}\text { Serra da } \\
\text { Mesa }\end{array}$ & 1,275 & 1,594 & 21 & 1.19 & 2,493 & 56.46 & 22.32 \\
\hline 11 & Furnas & 1,216 & 1,520 & 20 & 1.41 & 2,369 & 131.13 & 22.24 \\
\hline 12 & Emborcação & 1,192 & 1,490 & 20 & 4.17 & 2,384 & 96.80 & 22.84 \\
\hline 13 & Sobradinho & 1,050 & 1,313 & 18 & 0.42 & 2,176 & 110.88 & 23.65 \\
\hline 14 & Três Irmãos & 808 & 1,009 & 13 & 1.71 & 1,650 & 131.83 & 23.33 \\
\hline 15 & Capivara & 619 & 253 & 3 & 0.58 & 397 & 11.19 & 7.33 \\
\hline 16 & Nova Ponte & 510 & 638 & 9 & 1.89 & 1,011 & 80.56 & 22.64 \\
\hline 17 & Mascarenhas & 476 & 595 & 8 & 3.17 & 929 & 86.21 & 22.28 \\
\hline 18 & Chavantes & 414 & 518 & 7 & 1.73 & 807 & 52.71 & 22.25 \\
\hline 19 & Três Marias & 396 & 495 & 7 & 0.63 & 803 & 109.15 & 23.16 \\
\hline 20 & Promissão & 264 & 330 & 2 & 0.45 & 290 & 69.13 & 23.12 \\
\hline 21 & Barra Bonita & 141 & 176 & 2 & 0.76 & 279 & 75.34 & 22.65 \\
\hline 22 & Jurumirim & 101 & 101 & 1 & 0.30 & 155 & 33.12 & 17.56 \\
\hline & TOTAL & 31,479 & 33,938 & 452 & 2.2 & 53,256 & 56.7 & 20.01 \\
\hline
\end{tabular}

${ }^{1}$ Considering a $50 \%$ ground cover ratio - area of solar panels / total area occupied by the plant. 
Table 7: Brazilian electrical demand forecasting [14].

\begin{tabular}{lcccccc}
\hline & $\mathbf{2 0 1 8}$ & $\mathbf{2 0 1 9}$ & $\mathbf{2 0 2 0}$ & $\mathbf{2 0 2 1}$ & $\mathbf{2 0 2 2}$ & Average 2018-2022 \\
\hline Average MW & 66,645 & 69,109 & 71,718 & 74,480 & 77,423 & \\
\multirow{2}{*}{ Annual Increase } & 1,060 & 2,463 & 2,610 & 2,761 & 2,944 & 2,368 \\
& $1.6 \%$ & $3.7 \%$ & $3.8 \%$ & $3.9 \%$ & $4.0 \%$ & $3.8 \%$ \\
\hline
\end{tabular}

Among the proposed installation of $34 \mathrm{GW}$ of solar PV on their reservoirs, $14 \mathrm{PV}$ plants would surpass $1 \mathrm{GW}$ capacity. In comparison to the largest PV plants in the world that have already been commissioned, only Tucuruí, with $7 \mathrm{GW}$, and Ilha Solteira, with $4.3 \mathrm{GW}$, would fall outside the current range of large-scale PV plants state of the art, led by $1.5 \mathrm{GW}$ Tengger Desert, Ningxia, China, commissioned in 2016 [7].

In addition, $34 \mathrm{GW}$ additional solar capacity can increase annual power supply by approximately $6 \mathrm{GW}(53,256 \mathrm{GWh} / 8,760$ hours/year). Just as an exercise to have some numbers in mind, if we consider that this development took place in five years from 2018, the average increase of energy supply per year up to 2022 would be equivalent to $1,216 \mathrm{MW}$ or approximately half of the forecasted extra power needed (see Table 7).

Most of this energy is planned to come from new power plants based on renewable sources: hydro-9.0 GW (mainly in the North region, with small reservoirs), wind-3.0 GW, biomass-0.4 GW and large-scale solar PV-2.7 GW, but also $3.6 \mathrm{GW}$ of fossil fuel (mainly natural gas) [15]. This means the effect of compensating for fluctuating power output could even get worse in the near future.

Finally, Brazil has currently installed roughly $2 \mathrm{GW}$ of PV systems and in order to fully accomplishing this future alternative scenario, $34 \mathrm{GW}$ of solar PV should be installed in just five years. Nevertheless, looking for world statistics regarding the solar PV industry, it is remarkable to note that China has even surpassed this goal from 2011 to 2015, increasing the large-scale PV installed capacity from 2 to $37 \mathrm{GW}$ [13].

\section{CONCLUSIONS AND FINAL CONSIDERATIONS}

The variability of the power generation caused by the intermittent nature of the alternative renewable energy sources, such as solar and wind power systems, is a major concern related to the stability of electrical transmission grid lines, when their contributions rise to an important level. In Brazil the enormous increase in wind generation in the past decade-over 14 GW already installed in 2018, 45\% increase capacity per year since 2008 - and the degree to which its intermittency affects the electrical system has become an area of concern for generators and grid operators.

One of the most efficient ways to overcome this challenge in Brazil is to use its wellestablished net of HPP reservoirs with significant water storage. The deployment of PV power plants by adding floating solar collectors close to the dam of a reservoir compensates the unstable generation of these systems by adjusting hydropower output, whereas PV systems can compensate for the hydro energy deficiency in mid to long-term.

The 22 HPPs surveyed in this paper have significant water storage reservoirs and approximately $28 \%$ of total hydropower capacity installed in Brazil-31.5 of $114 \mathrm{MW}$. A project to add $34 \mathrm{GW}$ of floating PV systems on their reservoirs represents an additional CF of $20 \%$ to this installed hydro capacity or 53.3 TWh per year, equivalent to almost $10 \%$ of the Brazilian electricity demand in 2018. 
The feasibility of floating solar systems depends heavily on the prices of PV cells and some important items such as floating structures and waterproof electrical accessories, since the storage of energy in already built water reservoirs and the connection of the PV plant to the network taking advantage of HPP facilities are the cheapest ways to do both. The decision to go forward with this proposed solution can create a virtuous cycle for the solar industry in Brazil. The demand for solar cells would justify by itself efforts to speed up its supply, besides consisting of a high-impact measure, capable of boosting the use of PV solar energy in the country as a whole. At last, even a partial realization of this project could greatly increase the conventional solar park of $2.7 \mathrm{GW}$ planned for 2022 .

\section{REFERENCES}

[1] Chamber of Commercialization of Electric Energy - CCEE. Market Information. Consolidated Data. http://www.ccee.org.br/ (accessed 15 January 2019).

[2] Fang, W., Huang, Q., Huang, S., Yang, J., Meng, E. \& Li, Y., Optimal sizing of utility-scale photovoltaic power generation complementarily operating with hydropower: A case study of the world's largest hydro-photovoltaic plant. Energy Conversion and Management, 136, pp. 161-172, 2017. https://doi.org/10.1016/j.enconman.2017.01.012

[3] Energy Research Company. Statistical Yearbook of electricity. http://www.epe.gov.br/ (accessed 15 January 2019).

[4] Electrical System National Operator - ONS. Operational History. http://www.ons.org.br/ (accessed 25 January 2019).

[5] Farfan, J. \& Breyer, C., Combining floating solar photovoltaic power plants and hydropower reservoirs: A virtual battery of great global potential. Energy Procedia, 155, pp. 403-411, 2018. https://doi.org/10.1016/j.egypro.2018.11.038

[6] Perez, M., Perez, R., Ferguson, C.R. \& Schlemmer, J., Deploying effectively dispatchable PV on reservoirs: Comparing floating PV to other renewable technologies. Solar Energy, 174, pp. 837-847, 2018. https://doi.org/10.1016/j.solener.2018.08.088

[7] Solarplaza International BV, https://www.solarplaza.com/channels/top-10s/?page=2

[8] International Energy Agency - IEA. Technology Roadmap, Solar Thermal Electricity, 2014.

[9] Lemos, L.F.L., Starke, A.R., Boland, J., Cardemil, J.M., Machado, R.D. \& Colle, S., Assessment of solar radiation components in Brazil using the BRL model. Renewable Energy, 108, pp. 569-580, 2017. https://doi.org/10.1016/j.renene.2017.02.077

[10] NREL - National Renewable Energy Laboratory - U.S. Department of Energy, https:// maps.nrel.gov/swera/

[11] Lopez-Garcia, J. \& Tony Sample, T., Evolution of measured module characteristics versus labelled module characteristics of crystalline silicon based PV modules. Solar Energy, 160, pp. 252-259, 2018. https://doi.org/10.1016/j.solener.2017.12.018

[12] International Finance Corporation - IFC. A Project Developer's Guide to Utility-scale Solar Photovoltaic Power Plants, 2015.

[13] International Energy Agency - IEA. Photovoltaic Power Systems Program - Energy from the Desert: Very Large Scale PV Power Plants for Shifting to Renewable Energy Future. External Final Report IEA-PVPS, 2015.

[14] Technical Bulletin ONS. 2nd Quarterly Revision of Electric Demand Forecasting in the National Interconnected System 2018-2022.

[15] Electrical System National Operator - ONS. Energy Operating Plan 2018/2022. 